\title{
Decision Support System for Determination of Water Supply Distribution Decisions Using the Technique for Order Preference Method by Similarity to Ideal Solution (TOPSIS)
}

\author{
Henrycus Baik Handoko
}

Faculty of Science and Technology, Universitas Sanata Dharma, Indonesia

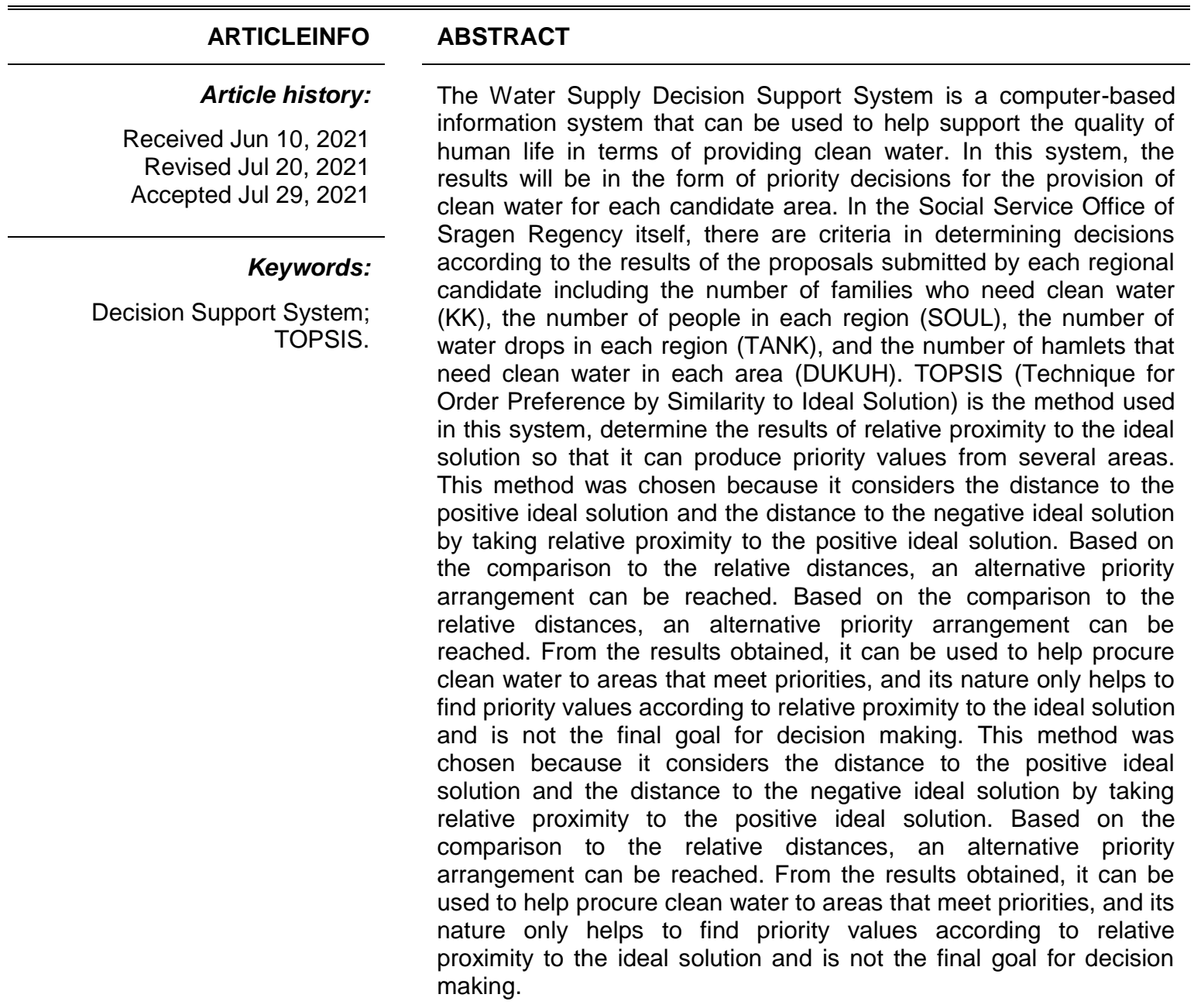

This is an open access article under the CC BY-NC license.

\section{Corresponding Author:}

Henrycus Good Handoko

Faculty of Science and Technology, Universitas Sanata Dharma , Indonesia

E-mail: hendrycusbaik12@gmail.com 


\section{INTRODUCTION}

Sragen Regency is one of the regencies in Central Java Province. Geographically, Sragen Regency is located on the border between Central Java and East Java. The boundaries of Sragen Regency are to the east of Ngawi Regency (East Java Province), to the west of Boyolali Regency, to the south of Karanganyar Regency, and to the north of Grobogan Regency. The area of Sragen Regency is $941.55 \mathrm{~km} 2$ which is divided into 20 sub-districts, 8 sub-districts, and 200 villages. Physiologically, the district of Sragen is divided into $40,037.93 \mathrm{Ha}(42.52 \%)$ of wet land (rice fields), $54,117.88 \mathrm{Ha}(57.48 \%)$ of dry land. Sragen Regency is located at 715 south latitude to 730 south longitude and 11045 east longitude to 11110 east longitude. The area of Sragen Regency is in the plains with an average height of $109 \mathrm{M}$ above sea level. Sragen has a tropical climate with daily temperatures ranging from $19-31 \mathrm{C}$. The average rainfall is below $3000 \mathrm{~mm}$ per year with less than 150 rainy days per year. The population of Sragen based on 2005 data is 865,417 people, consisting of 427,253 male residents and 438,164 female residents. The average population density is 919 people/km2. area : 94,155 ha, paddy field area : 40,129 ha, and dry land : 54,026 ha.

Arifin and Hartati studied the distribution of clean water under the title Clean Water Decision Support System with Fuzzy Interger Transportation. In this study, the resulting goal is to solve distribution problems with a fuzzy integer transportation model approach showing better results, namely the minimum total distribution costs with the total distributed water approaching customer expectations (Arifin A \& Hartati S, 2011).

TOPSIS (Technique for Order Preference by Similarity to Ideal Solution) is a multi-criteria decision-making method. This method is widely used to complete practical decision making. This is because the concept is simple and easy to understand, computationally efficient, and has the ability to measure the relative performance of decision alternatives. In determining the allocation of clean water supply distribution, there are several criteria used by the Sragen district government. These criteria include: the number of families and the number of hamlets that need clean water in each area according to the proposals submitted by each sub-district, the total number of people per area, and the number of tanks to be distributed.

\section{METHOD}

This research aims to determine the priority areas for clean water assistance. The input used is in the form of mapping data which becomes the criteria in determining including the number of households that need clean water, the number of people in each area, the number of water drops in each area, and the number of hamlets that need clean water assistance. The data will be processed to produce the final calculation output. Later the system is expected to be able to assist DINSOS in determining priorities for areas that need clean water. Research design :

a. Study of literature

Learn the theory of decision-making assistance systems and the TOPSIS method (Technique For Others Reference by SimiLarity to Ideal Solution) in the construction of SPPK. Literature source in the form of international journals, supporting websites, and books related to decision-making support systems.

b. Data collection

The data collection method used in writing this final project.

c. Data used

The data used is data from mapping the need for clean water in each region the period of 15 July to 17 November 2015 . The mapping data produces data on the number of households, the number of people, and hamlets that need clean water in each area and demand water drops net in tank units. The data is also used for testing basis this system.

d. Data collection technique

Interviews were conducted with the head of DINSOS (Social Service) of Sragen Regency and IT staff of PDAM of Sragen Regency. The purpose of conducting the interview is related to the procedure criteria. 


\section{RESULTS AND DISCUSSIONS}

The TOPSIS (Technique for Order Preference by Similarity to Ideal Solution) method is based on the concept that the best chosen alternative only has the shortest distance from the positive ideal solution but also has the longest distance from the negative ideal solution. The following is one of the resolutions of the clean water allocation case from the mapping results for the period 15 July to 17 November 2015: Determining the Alternatives and Aspects to be used.

Table 1.

Mapping data table for the period 15 July to 17 November 2015

\begin{tabular}{cccccc}
\hline No & Village Name & KK & SOUL & TANK & HAMLET \\
\cline { 3 - 6 } 1 & Bagor & 169 & 563 & 12 & 2 \\
2 & Baleharjo & 239 & 1003 & 12 & 2 \\
3 & Banyurip & 1085 & 3275 & 35 & 4 \\
4 & Cepoko & 198 & 292 & 16 & 2 \\
5 & Dawung & 162 & 642 & 12 & 2 \\
6 & Hamlet & 428 & 1171 & 18 & 3 \\
7 & Galeh & 125 & 503 & 30 & 3 \\
8 & Gebang & 184 & 736 & 9 & 1 \\
9 & shaking & 226 & 1076 & 16 & 1 \\
10 & Gesi & 95 & 370 & 8 & 1 \\
11 & Gilirejo & 217 & 1037 & 25 & 3 \\
12 & New Gilirejo & 440 & 1523 & 36 & 3 \\
13 & guard & 350 & 1050 & 13 & 2 \\
14 & Jenar & 215 & 938 & 18 & 3 \\
15 & Jono & 120 & 534 & 6 & 1 \\
\hline
\end{tabular}

1. Normalization Matrix

From the results of the data table for the mapping of water dropping for the period 15 July to 17 November 2015, it will be normalized. Here are the steps:

a. Obtaining the $\mathrm{Xij}$. value

The case was taken from Bagor village, the mapping data table obtained the value: $\mathrm{KK}$ 169, SOUL 563, TANK 12, HAMLET 2

Table 2.

Calculation Table

\begin{tabular}{ccccc}
\hline Village Name & KK & SOUL & TANK & HAMLET \\
\hline Bagor & 28561 & 316969 & 144 & 4 \\
Baleharjo & 57121 & 1006009 & 144 & 4 \\
Banyurip & 1177225 & 10725625 & 1225 & 16 \\
Cepoko & 39204 & 85264 & 256 & 4 \\
Dawung & 26244 & 412164 & 144 & 4 \\
Hamlet & 183184 & 1371241 & 324 & 9 \\
Galeh & 15625 & 253009 & 900 & 9 \\
Gebang & 33856 & 541696 & 81 & 1 \\
shaking & 51076 & 1157776 & 256 & 1 \\
Gesi & 9025 & 136900 & 64 & 1 \\
Gilirejo & 47089 & 1075369 & 625 & 9 \\
New Gilirejo & 193600 & 2319529 & 1296 & 9 \\
guard & 122500 & 1102500 & 169 & 4 \\
Jenar & 46225 & 879844 & 324 & 9 \\
Jono & 14400 & 285156 & 36 & 1 \\
\hline
\end{tabular}

b. Getting the root value of the Xij . subtotal

$$
\sqrt{\sum_{i=1}^{m} x_{i j}{ }^{2}}
$$


Table 3.

Table of roots of the whole sum 2

\begin{tabular}{ccccc}
\hline & KK & SOUL & TANK & HAMLET \\
\cline { 2 - 5 } TOTAL & 2760408 & 32890411 & 10474 & 144 \\
ROOT & 1661.45 & 5735.016 & 102.343 & 12 \\
\hline
\end{tabular}

Getting the results of the Normalized matrix

$$
r \text { ij }=\frac{\mathrm{K}_{\mathrm{ij}}}{\sqrt{\sum_{\mathrm{i}=1}^{m} \mathrm{~K}^{2} \mathrm{ij}}}
$$

After going through several stages starting from obtaining the value of $\mathrm{X} 2 \mathrm{ij}$ to the root of the total value of $X 2 \mathrm{ij}$, then from the 30 villages the value of each village will be normalized. The normalized value is obtained from the $\mathrm{X} 2 \mathrm{ij}$ value and then divided by the root of the $\mathrm{X} 2 \mathrm{ij}$ subtotal value. Here's the solution:

Table 4.

Normalization matrix value table $\square \mathrm{ij}$

\begin{tabular}{cccccc}
\hline No & Village Name & KK & SOUL & TANK & HAMLET \\
\hline 1 & Bagor & 0.101718528 & 0.098169 & 0.11725 & 0.16667 \\
2 & Baleharjo & 0.143850462 & 0.174891 & 0.11725 & 0.16667 \\
3 & Banyurip & 0.653044986 & 0.571053 & 0.34199 & 0.33333 \\
4 & Cepoko & 0.119173186 & 0.050915 & 0.15634 & 0.16667 \\
5 & Dawung & 0.097505334 & 0.111944 & 0.11725 & 0.16667 \\
6 & Hamlet & 0.257606686 & 0.204184 & 0.17588 & 0.25 \\
7 & Galeh & 0.075235597 & 0.087707 & 0.29313 & 0.25 \\
8 & Gebang & 0.1107468 & 0.128334 & 0.08794 & 0.08333 \\
9 & Shaking & 0.13602596 & 0.187619 & 0.15634 & 0.08333 \\
10 & Gesi & 0.07179054 & 0.064516 & 0.07817 & 0.08333 \\
11 & Gilirejo & 0.130608997 & 0.180819 & 0.24428 & 0.25 \\
12 & New Gilirejo & 0.264829303 & 0.265562 & 0.35176 & 0.25 \\
13 & Guard & 0.210659673 & 0.183086 & 0.12702 & 0.16667 \\
14 & Jenar & 0.129405228 & 0.163557 & 0.17588 & 0.25 \\
15 & Jono & 0.072226174 & 0.093112 & 0.05863 & 0.08333 \\
\hline
\end{tabular}

c. Weighted Matrix Normalization

In this problem, the weight of each independent criterion is obtained, the following is the weight value of $\mathrm{Wj}$ :

Table 5.

Weight Value Table

\begin{tabular}{cccc}
\hline \multicolumn{4}{c}{ Weight } \\
\hline KK (w1) & SOUL (w2) & TANK (W3) & hamlet (W4) \\
5 & 2 & 5 & 3 \\
\hline
\end{tabular}

$$
\mathbf{V}_{\mathrm{ij}}=\mathbf{W}_{\mathrm{j}} \times \mathbf{R}_{\mathrm{ij}}
$$

Of the 15 villages listed to get a weighted normalization value, the normalization value is multiplied by the available weight value, the following is the solution:

Table 6.

\begin{tabular}{|c|c|c|c|c|c|}
\hline & Village Name & $\mathrm{KK}$ & SOUL & TANK & HAMLET \\
\hline 1 & Bagor & 0.508592639 & 0.196338 & 0.58627 & 0.5 \\
\hline 2 & Baleharjo & 0.719252312 & 0.349781 & 0.58627 & 0.5 \\
\hline 3 & Banyurip & 3.265224931 & 1.142107 & 1.70994 & 1 \\
\hline 4 & Cepoko & 0.595865932 & 0.011831 & 0.78169 & 0.5 \\
\hline 5 & Dawung & 0.487526672 & 0.223888 & 0.58627 & 0.5 \\
\hline
\end{tabular}

Weighted normalized matrix table ij 


\begin{tabular}{cccccc}
\hline & Village Name & KK & SOUL & TANK & HAMLET \\
\cline { 2 - 6 } 6 & Hamlet & 1.288033429 & 0.408369 & 0.8794 & 0.75 \\
7 & Galeh & 0.376177987 & 0.175414 & 1.46567 & 0.75 \\
8 & Gebang & 0.553733998 & 0.256669 & 0.4397 & 0.25 \\
9 & shaking & 0.680129801 & 0.375239 & 0.78169 & 0.25 \\
10 & Gesi & 0.28589527 & 0.129032 & 0.39084 & 0.25 \\
11 & Gilirejo & 0.653044986 & 0.361638 & 1.22139 & 0.75 \\
12 & New Gilirejo & 1.324146516 & 0.531123 & 1.7588 & 0.75 \\
13 & Guard & 1.053298365 & 0.366172 & 0.63512 & 0.5 \\
14 & Jenar & 0.647026138 & 0.327113 & 0.8794 & 0.75 \\
15 & Jono & 0.361130868 & 0.186224 & 0.29313 & 0.25 \\
\hline
\end{tabular}

d. Calculating Positive and Negative Separation Distance

After the weighted normalization results are obtained, then the maximum and minimum values for each criterion are searched.

PIS $=A^{+}=\left\{V_{1}^{+}, V_{2}^{+} \ldots, V_{n}^{+}\right\}$, where: $V_{j}^{+}=\left\{\left(\operatorname{maxi}\left(V_{i j}\right)\right.\right.$ if $\left.j \in J\right) ;\left(\operatorname{mini} V_{i j}\right.$ if $\left.\left.j \in J^{\prime}\right)\right\}$

NIS $=A^{-}=\left\{V_{1}^{-}, V_{2}^{-} \ldots, V_{n}^{-}\right\}$, where: $V_{j}^{-}=\left\{\left(\operatorname{mini}\left(V_{i j}\right)\right.\right.$ if $\left.j \in J\right) ;\left(\operatorname{maxi} V_{i j}\right.$ if $\left.\left.j \in J^{\prime}\right)\right\}$

The maximum and minimum values are to determine the positive ideal solution and the negative ideal solution. The following are the maximum and minimum results obtained from the weighted normalization table:

Table 7.

Table of Positive and Negative Ideal Solutions

\begin{tabular}{|c|c|c|c|c|}
\hline & $\mathrm{KK}$ & SOUL & TANK & HAMLET \\
\hline MAX & 3.265224931 & 1.142107 & 1.7588 & 1 \\
\hline MIN & 0.087273293 & 0.038361 & 0.19542 & 0.25 \\
\hline
\end{tabular}

Calculate the separation size. This separation measure is a measurement of the distance from an alternative to a positive ideal solution and a negative ideal solution.

Get a positive ideal solution value:

$$
S_{\mathrm{i}+}=\sqrt{\sum_{\mathrm{j}=1}^{m}\left(V_{\mathrm{ij}}-V_{\mathrm{j}^{+}}\right) 2} \text { dengan } i=1,2,3, \ldots \ldots . m
$$

Of the 15 villages listed to get a positive ideal solution, the normalized value of each alternative is reduced by the maximum value which is then squared, along with the solution.

Table 8.

Calculation Table

\begin{tabular}{|c|c|c|c|c|c|}
\hline & Village Name & KK & SOUL & TANK & HAMLET \\
\hline \multirow{3}{*}{1} & \multirow{2}{*}{ Bagor } & $(0.508592$ & $(0.196342$ & $(0.586272$ & $(0.52$ \\
& & $3.265224931)$ & $1.142107)$ & $1.7588)$ & $1)$ \\
& & $=7.599022$ & $=0.89448$ & $=1.37483$ & $=0.25$ \\
\hline
\end{tabular}

Then it continues in each village with the same calculation. After each alternative is calculated. Next find the value of the root, the following is the solution

$$
S_{\mathrm{i}+}=\underset{\mathrm{j}=1}{\sqrt{\sum_{\mathrm{ij}}}\left(V_{\mathrm{j}}^{+}\right) 2}
$$


Table 9.

Calculation Table si+

\begin{tabular}{ccc}
\multicolumn{3}{c}{ Calculation Table si+ } \\
\hline 1 & Bagor & 3.180933 \\
\hline 2 & Baleharjo & 2.955434 \\
3 & Banyurip & 0.048856 \\
4 & Cepoko & 3.067963 \\
5 & Dawung & 3.19117 \\
6 & Hamlet & 2.298587 \\
7 & Galeh & 3.070751 \\
8 & Gebang & 3.230899 \\
9 & Shaking & 2.964464 \\
10 & Gesi & 3.512339 \\
11 & Gilirejo & 2.789969 \\
12 & New Gilirejo & 2.050265 \\
13 & Guard & 2.647139 \\
14 & Jenar & 2.890506 \\
15 & Jono & 3.472485 \\
\hline
\end{tabular}

Get the value of the negative ideal solution:

$$
S_{\mathrm{i}-}=\sqrt{\sum_{\mathrm{j}=1}^{m}\left(V_{\mathrm{ij}}-V_{\mathbf{j}}^{-}\right) 2 \text { dengan } i=1,2,3, \ldots \ldots . m}
$$

Of the 15 villages listed to get a negative ideal solution, the normalized value of each alternative is reduced by the minimum value which is then squared, along with the solution.

Table 10.

Calculation Table si+

\begin{tabular}{cccccr}
\hline No & Village Name & \multicolumn{1}{c}{ KK } & \multicolumn{1}{c}{ SOUL } & \multicolumn{1}{c}{ TANK } & HAMLET \\
\cline { 3 - 6 } 1 & \multirow{3}{*}{ Bagor } & $(0.508592$ & $(0.196342$ & $(0.586272$ & $(0.52$ \\
& & $0.087273293)$ & $0.038361)$ & $0.19542)$ & $0.25)$ \\
& $=0.17751$ & $=0.02496$ & $=0.15276$ & $=0.0625$ \\
\hline
\end{tabular}

Then it continues in each village with the same calculation. After each alternative is calculated. Next find the value of the root, the following is the solution.

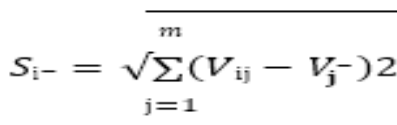

Table 11.

Calculation Table si+

\begin{tabular}{ccc}
\hline 1 & Bagor & 0.64632 \\
2 & Baleharjo & 0.84359 \\
3 & Banyurip & 3.76482 \\
4 & Cepoko & 0.81786 \\
5 & Dawung & 0.64022 \\
6 & Hamlet & 1.51544 \\
7 & Galeh & 1.40206 \\
8 & Gebang & 0.57001 \\
9 & Shaking & 0.89926 \\
10 & Gesi & 0.29302 \\
11 & Gilirejo & 1.31423 \\
12 & New Gilirejo & 2.11348 \\
13 & Guard & 1.13864 \\
14 & Jenar & 1.05571 \\
15 & Jono & 0.3262 \\
\hline
\end{tabular}


e. Calculating Relative Proximity

From the results of a positive ideal solution and a negative ideal solution, from the 15 villages the preference values for each alternative can be calculated.

$$
C_{\mathrm{i}}=\frac{{ }_{+}^{{ }^{-}}}{S_{\mathrm{i}}+S_{\mathrm{i}}}=0 \leq C_{\mathrm{i}} \leq 1
$$

Of the 30 villages listed to get a preference value, the value of the negative ideal solution for each alternative is divided by the value of the negative ideal solution plus the positive ideal solution, as follows:

Table 12.

Relative Proximity calculation table

\begin{tabular}{rcc}
\hline No & $\begin{array}{c}\text { Village } \\
\text { Name }\end{array}$ & $\begin{array}{c}\text { Relative } \\
\text { Proximity }\end{array}$ \\
\hline 1 & Bagor & 0.168872 \\
2 & Baleharjo & 0.222054 \\
3 & Banyurip & 0.987189 \\
4 & Cepoko & 0.210474 \\
5 & Dawung & 0.167099 \\
6 & Hamlet & 0.397333 \\
7 & Galeh & 0.313463 \\
8 & Gebang & 0.149968 \\
9 & Shaking & 0.232745 \\
10 & Gesi & 0.077002 \\
11 & Gilirejo & 0.320217 \\
12 & New Gilirejo & 0.507592 \\
13 & Guard & 0.300768 \\
14 & Jenar & 0.267525 \\
15 & Jono & 0.085873 \\
\hline
\end{tabular}

\section{Ranking}

From the 30 villages, it is found that relatively clean water is allocated to support the quality of human life. Here are the ranking results:

Table 12.

Ranking Table

\begin{tabular}{ccc}
\hline No & Village Name & Rank \\
\hline 1 & Banyurip & 0.98719 \\
2 & Cooking & 0.51534 \\
3 & New Gilirejo & 0.50759 \\
4 & Ngargotirto & 0.42154 \\
5 & Hangout & 0.41447 \\
6 & Hamlet & 0.39733 \\
7 & Gilirejo & 0.32022 \\
8 & Galeh & 0.31346 \\
9 & Guard & 0.30077 \\
10 & Jenar & 0.26752 \\
11 & Katelan & 0.24358 \\
12 & Shaking & 0.23274 \\
13 & Pare & 0.22293 \\
14 & Baleharjo & 0.22205 \\
15 & Cepoko & 0.21047 \\
\hline
\end{tabular}




\section{Allocation}

From the 30 villages with alternative ranking results, the provider provides the amount of water discharge in the form of tanks, 1 truck tank containing 5000 liters. In the period from 15 July to 17 November 2015 the Social Service Office of Sragen Regency provided 7 trucks each month with a total of 5000 liters of each truck tank. Here's the review: Water supply $=(7$ tanks $\times 5000$ liters $) \times 5$ months $=175000$ liters. From the ranking results, the total value of each alternative is obtained. The following is the total value obtained: So with the total results of each alternative and the available water supply, the clean water allocation is calculated as follows:

Table 13.

\begin{tabular}{cc}
\multicolumn{2}{c}{ Allocation Table } \\
\hline Village Name & Liter \\
\hline Banyurip & 23214,79683 \\
Cooking & 12118.75464 \\
New Gilirejo & 11936.50536 \\
Ngargotirto & 9912.950349 \\
Hangout & 9746.691965 \\
Pare & 5242.430188 \\
Baleharjo & 5221.736075 \\
Cepoko & 4949.420363 \\
Slendro & 4898.390562 \\
Kedawung & 4444.766204 \\
Tlogotirto & 4432.537864 \\
Poleng & 3988.08476 \\
Dawung & 3929.529827 \\
Gebang & 3526.700109 \\
Jono & 2019.32212 \\
\hline
\end{tabular}

After testing the system and manual calculations on the data for the period 15 July to 17 November 2015 by applying the TOPSIS (Technique For Others Reference by Similarity to Ideal Solution) method, it was obtained that the relative priority for clean water distribution assistance was Banyurip Village with a value of 0.98719 , which means approaching the value of the ideal solution. The results of the allocation of clean water in Banyurip Village are 23214,79683 liters. Then the output is obtained as a benchmark for consideration of the distribution of clean water from the village with the biggest priority to the village with the smallest priority.

\section{CONCLUSION}

Based on the results of the research and discussion that have been described previously, it can be concluded that the TOPSIS (Technique For Others Reference by Similarity to Ideal Solution) method can be applied in a Decision Support System for the provision of clean water supply assistance. The test results manually using Microsoft excel and the system created give the same results.

\section{References}

Srikrishna S, Sreenivasulu Reddy. A, Vani S (2014). International Journal of Engineering Research and General Science: A New Car Selection in the Market using TOPSIS Technique.

Arifin A \& Hartati S, 2011. Jurnal: Aplikasi Pendukung Keputusan Distribusi Air Bersih dengan Fuzzy Interger Transportation.

Anwar, Khoirul, 2012. 130199274-Topsis-Method.

N.Sora, 2014. Basis data dan Sistem Basis data. Diperoleh 24 November 2015. htpp://www.pengertianku.net/2014/06/pengertian-basis-data-dan-sistem- basis.html

Humas. Sekilas Kabupaten Sragen. Diperoleh 2 Desember 2015. http://www.humaskabsragen.com/sekilaskabupaten-sragen/

Silberschatz A, 2002. Database system concept. Diperoleh 24 November 2015. USU, 2014. Diperoleh 5 Januari 2016.

http://repository.usu.ac.id/bitstream/123456789/34901/4/Chapter\%20II.pdf

Turban Efraim, Jay E. Aronson, Ting-Peng Liang. (2005). Decision Support System and Inteligent Systems. 
Yogyakarta : Andi.

Nurochman, 2011.

Makalah Air Bersih. Diperoleh

27

November

2015.

https://athaagatha.wordpress.com/2012/11/28/makalah-air-bersih/

Whitten, Jeffrey L. (2004). Systes Analysis and Design Methods. 